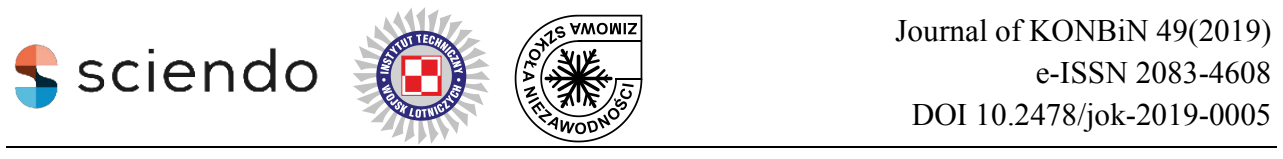

Monika KARDACH, Paweł FUĆ, Marta GALANT, Marta MACIEJEWSKA Poznan University of Technology (Politechnika Poznańska)

\title{
RISK ASSESSMENT OF REMOTELY PILOTED AIRCRAFT SYSTEMS
}

\section{Ocena ryzyka zagrożeń w systemach użytkowania bezzałogowych statków powietrznych}

\begin{abstract}
The intensive growth in the popularity of Remotely Piloted Aircraft Systems (RPAS) used for recreational, sporting and other purposes, may lead to an increase in accidents and incidents involving them. Therefore, it is advisable to raise the awareness of all users, related to safety issues, to harmonize standards and procedures applicable at international and national level. The article presents the legal conditions for unmanned operations and the risk assessment methods used in areas of human activity. On this basis, an original method of risk assessment in unmanned systems was proposed. The method can be part of the operating instructions of the RPAS operator. At the end, final conclusions were drawn up.
\end{abstract}

Keywords: remotely piloted aircraft system, risk assessment, operational instruction

Streszczenie: Intensywny wzrost popularności bezzałogowych statków powietrznych wykorzystywanych zarówno $w$ celach rekreacyjnych, sportowych, jak i innych, może być przyczyną zwiększenia liczby wypadków i incydentów z ich udziałem. Celowe jest więc podnoszenie świadomości użytkowników zwiazanej z zagadnieniami bezpieczeństwa oraz ujednolicanie norm i procedur obowiazujacych na poziomie międzynarodowym i krajowym. $W$ artykule przedstawiono uwarunkowania prawne dotyczace operacji bezzałogowych statków powietrznych. Dokonano przegladu metod oceny ryzyka wykorzystywanych $w$ różnych dziedzinach działalności ludzkiej. Zaproponowano autorska metodę oceny ryzyka zagrożeń $w$ systemach użytkowania bezzałogowych statków powietrznych, która może zostać częścia instrukcji operacyjnej operatora lotniczego. Na zakończenie, podano przyktady postępowania wobec ryzyka i sporzadzono wnioski.

Słowa kluczowe: bezzałogowe statki powietrzne, ocena ryzyka zagrożeń, instrukcja operacyjna 


\section{Introduction}

Very difficult working environment, consisting of many systems and subsystems is a characteristic of aviation (also unmanned), therefore itis important to maintain adequate risk levels to ensure flights' safety. Flights' safety understood as conditions that ensure that the flight is carried out by an aircraft without endangering the safety of the crew, passengers and the ship itself as well as people on the ground and ground equipment [5] is determined by many variables: pilots, airports' infrastructure, aircraft's technical condition, air space management, environment and many others. The use of Unmanned Aircraft Systems (UAS) to perform transportation tasks is an opportunity to change the pilot's working environment to more people friendly one. Increasingly, the aviation domains associated with recreation are becoming an opportunity for individual people to run their own business, as they do not require as much financial expenses as entering the air carriers' market. Therefore, it is necessary to ensure an adequate safety level in all areas of aviation activity. Unmanned Aerial Vehicles (UAV) can be use in many different aspects of human activity, e.g. for measuring and assessing building structures, measuring air pollution levels, traffic obstructions, emergency medical services, meteorological measurements, transmitting internet signal without building an expensive infrastructure and in photography, photogrammetry and filming. A qualification certificate is required to perform any of these activities for purposes other than sorts or recreation. So far, around 6800 qualifications have been issued in Poland and the number of commercial operators is constantly growing [3].

\section{Unmanned Aerial Vehicles regulations}

The entities involved in proceeding legal regulations as well as research and development works related to UAS are among others: International Civil Aviation Organization (ICAO), European Aviation Safety Agency (EASA), European Organization for the Safety of Air Navigation (EUROCONTROL), Joint Authorities for Rulemaking on Unmanned Systems (JARUS) and national civil aviation authorities. Rules for using UAV in Polish airspace are created on their basis. Main rules are defined by the Act of July 3, 2002 - Aviation Law and its implementing regulations, in particular art. 126, art. 104, art. $153 \mathrm{c}$, art. 33 par. 2. The detailed rules of unmanned operations in Poland are described in three regulations of the Minister of Transport, Construction and Maritime Economy. According to it, polish law distinguishes sports and leisure, or other use of UAS. 
Operators of other than sport or leisure flight are obligated to have a Civil Aviation Authority (CAA) qualifications, issued to the person who have undergone aeromedical examinations, passed theoretical and practical examinations and has appropriate insurance purchased. Whereby an unmanned aircraft operator is a person, organization or undertaking offering or engaged in carrying out UAS operations within the meaning of ICAO [4]. Due to the lack of specification of the UAV operator/ pilot definition in Polish law, the CAA is working on differentiating between the operator - the UAV pilot and the operator - organization, enterprise. The qualification certificate may allow operations in Visual Line Of Sight (VLOS) or Beyond Visual Line Of Sight (BVLOS). The allowances may be limited to specific mass ranges (from "less than $5 \mathrm{~kg}$ " class to "less than $150 \mathrm{~kg}$ " and UAV classes (airplane, helicopter, aerostat or multirotor). BVLOS flights are only possible in separate areas of the airspace (until January $31^{\text {st }} 2019$ ).

The obligation to have an operation manual by an operator performing an UAV flight for a purpose other than sporting or leisure results from annex 6a to the Regulation of the Minister of Transport, Construction and Maritime Economy of March 26, 2013 on the exclusion of certain provisions of the Aviation Act for certain types of aircraft and determine the conditions and requirements for the use of these aircrafts (so-called Exclusion Regulation) [7]. The manual should be prepared by the entity providing air services (e.g. a company) and contains in particular [6]:

- air services provider's data,

- the list of the UAV in use,

- personnel data with possessed licenses,

- the description of risk analysis process of performed air operations in relation to UAV used,

- the list of control activities carried out before start and after landing,

- procedures and rules of air operations,

- emergency procedures.

Risk analysis is a systematic use of all information available in order to hazards identification, estimated their risk and its evaluation [1] it is a part of risk assessment algorithm.

To manage the UAS services market properly, it is necessary to create the classification, which would be suitable for different requirements in relation to the created structures. According to the Exclusion Regulation UAV are divided into three weight categories [7]:

- $<5 \mathrm{~kg}$,

- $5 \mathrm{~kg}-25 \mathrm{~kg}$,

- $25 \mathrm{~kg}-150 \mathrm{~kg}$. 
During webinar DroneRules.eu a division, depending on the Maximum TakeOff Mass (MTOM), altitude and UAV technical characteristic was proposed. The division is presented in table 1 and is considered suitable for use in the proprietary risk assessment method.

Table 1

The division of Unmanned Aerial Vehicles into subcategories [own study based on 2]

\begin{tabular}{|l|l|l|l||}
\hline \multicolumn{1}{|c|}{ UAV class } & \multicolumn{1}{|c|}{ MTOM } & \multicolumn{1}{|c|}{ Max. altitude } & \multicolumn{1}{|c|}{ Technical characteristic } \\
\hline C0 & $250 \mathrm{~g}$ & Up to $50 \mathrm{~m} \mathrm{AGL}$ & Follow me mode, user manual \\
\hline $\mathrm{C} 1$ & $<900 \mathrm{~g}$ & Up to $120 \mathrm{~m}$ AGL & $\begin{array}{l}\text { Follow me mode, user manual, lights, } \\
\text { battery level }\end{array}$ \\
\hline $\mathrm{C} 2$ & $<4 \mathrm{~kg}$ & Up to $120 \mathrm{~m}$ AGL & $\begin{array}{l}\text { Post signal lost control, user manual, } \\
\text { lights, battery level }\end{array}$ \\
\hline $\mathrm{C} 3$ & $<25 \mathrm{~kg}$ & Up to $120 \mathrm{~m}$ AGL & $\begin{array}{l}\text { Post signal lost control, user manual, } \\
\text { lights, battery level }\end{array}$ \\
\hline C4 & $<25 \mathrm{~kg}$ & - & $\begin{array}{l}\text { Designed and produced in accordance } \\
\text { with the principles of safe flying }\end{array}$ \\
\hline
\end{tabular}

\section{Risk assessment methods' classification}

Risk assessment methods can be divided into qualitative and quantitative methods. In qualitative ones, the values of risk measures are subject to prioritization in risk levels (e.g. negligible, small, significant, large). They allow estimating the level of probability of an unwanted event and the level of losses. In quantitative methods, the values of risk measures are numbers that can be subject to prioritization in risk levels. Quantitative methods are more accurate but require expensive research and analysis. Among the quantitative methods, deductive methods (e.g. Fault Tree Analysis) can be distinguish and inductive ones (e.g. Event Tree Analysis). The qualitative methods are, among others: Preliminary Hazard Analysis, Risk Score, Five Steps. The division of selected methods is shown in fig. 1. 


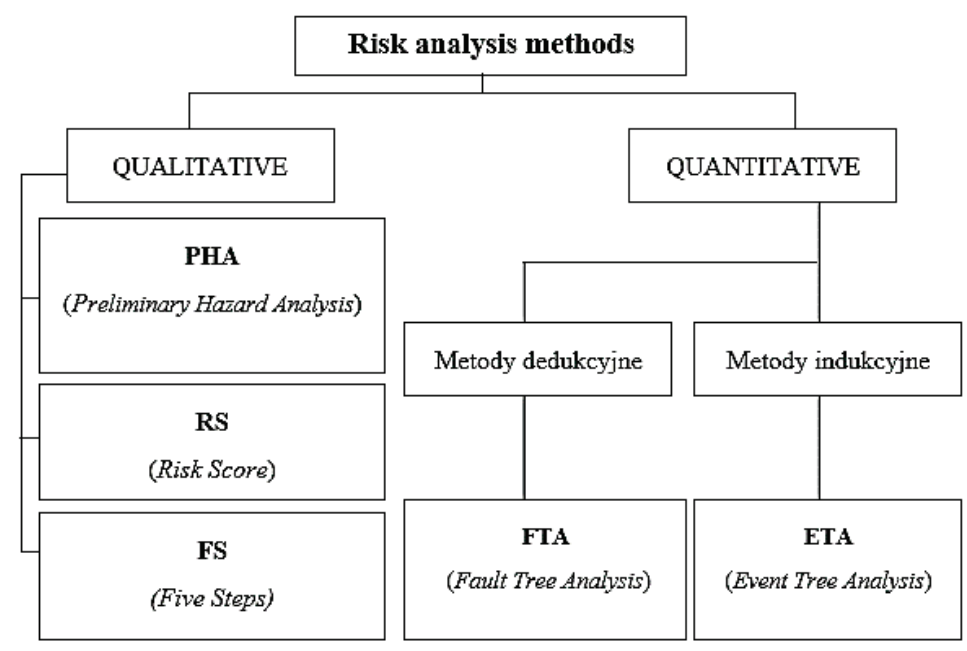

Fig. 1. Selected risk analysis methods division [own study based on 1]

Among the qualitative methods of risk analysis, the most common are those, where the risk is based on connection between probability of hazard activation and the consequence of unwanted event. None of the methods is directly adapted to the UAS risk assessment, therefore it was decided to propose its own method of conducting such an assessment.

\section{The original risk assessment method}

The M\&M is a quantitative method for risk assessment in UAV operations. In this method it was assumed, that the risk is a product of two elements, referring to:

1) criterion for potential losses, which is the sum of losses related to: people and infrastructure on the ground, other aircrafts in the air,

2) criterion for the probability of an unwanted event.

By taking into consideration the probability of occurring an unwanted event, it is possible to estimate of rare events but with serious consequences. The risk value (R) in the $\mathrm{M} \& \mathrm{M}$ method is calculated according to the formula:

$$
R=\left(r_{1}+r_{2}+r_{3}\right) * r_{4}
$$

Where,

$\mathrm{r}_{1}$ - risk component corresponding to the criterion of material damage resulting from the hazards' activation, 
$\mathrm{r}_{2}$ - risk component corresponding to the criterion of airspace in use,

$\mathrm{r}_{3}$ - risk component corresponding to the criterion of number of people exposed,

$\mathrm{r}_{4}$ - risk component corresponding to the criterion of probability.

The value of the $r_{1}$ coefficient is determined on the basis of potential destruction costs of the infrastructure over which the flight is performed (table 2).

Table 2

Valuation of material losses

\begin{tabular}{||l|c|l|}
\hline \multicolumn{1}{|c|}{ Material losses } & $\mathrm{r}_{1}$ value & \multicolumn{1}{c|}{ Form of land cover } \\
\hline$>30 \mathrm{mln}$ PLN & 10 & Critical infrastructure \\
\hline 1-30 mln PLN & 9 & Highly urbanized area \\
\hline 0,3-1 mln PLN & 8 & Lightly urbanized area \\
\hline 30-300 ths. PLN & 6 & $\begin{array}{l}\text { Industrial and commercial areas, } \\
\text { construction sites, sports and leisure } \\
\text { facilities }\end{array}$ \\
\hline 3-30 ths. PLN & 4 & Water reservoirs, beaches \\
\hline$<3$ ths. PLN & 2 & Forests, meadows, agricultural areas \\
\hline
\end{tabular}

The value of the $r_{2}$ coefficient is obtained depending on the airspace in which the flight is performed (table 3 ).

Table 3

Indicators related to the airspace category

\begin{tabular}{|c|l|}
\hline $\begin{array}{c}\text { Airspace } \\
\text { category } \\
\text { indicator }\end{array}$ & \multicolumn{1}{|c|}{ Operating space } \\
\hline 1 & $\begin{array}{l}\text { Operations in activated Temporary Segregated Areas (TSA) or TSA } \\
\text { Feeding Route (TFR) }\end{array}$ \\
\hline 2 & Operations in Restricted areas (R) \\
\hline 3 & $\begin{array}{l}\text { Operations in Temporary Restricted Areas (TRA) or Exercises Areas } \\
\text { (EA) }\end{array}$ \\
\hline 4 & $\begin{array}{l}\text { Operations in C class airspace with permanent radio communication } \\
\text { and transponder }\end{array}$ \\
\hline 5 & $\begin{array}{l}\text { Operations in Controlled Zones (CTR) under conditions other than 1 to } \\
6 \mathrm{~km} \text { from the airport boundary below 30 m (it the UAV weighs } \leq 600\end{array}$ \\
\hline
\end{tabular}




\begin{tabular}{|c|c|}
\hline $\begin{array}{l}\text { Airspace } \\
\text { category } \\
\text { indicator }\end{array}$ & Operating space \\
\hline & $\begin{array}{l}\text { g) or more than } 6 \mathrm{~km} \text { from the airport boundary below } 100 \mathrm{~m} \text { (if the } \\
\text { UAV weighs }<25 \mathrm{~kg} \text { ) }\end{array}$ \\
\hline 6 & $\begin{array}{l}\text { Operations in Military Controlled Zones (MCTR), activated Military } \\
\text { Routs (MRT), Prohibited (P) or Dangerous Areas (D) }\end{array}$ \\
\hline 7 & Operations in Air Traffic Zones (ATZ) \\
\hline 8 & $\begin{array}{l}\text { Operations in } \mathrm{G} \text { class } 300 \mathrm{~m} \text { below the built-up area or below } 150 \mathrm{~m} \\
\text { above the undeveloped area }\end{array}$ \\
\hline 9 & $\begin{array}{l}\text { Operations in } \mathrm{G} \text { class } 300 \mathrm{~m} \text { above the built-up area or above } 150 \mathrm{~m} \\
\text { above the undeveloped area }\end{array}$ \\
\hline 10 & $\begin{array}{l}\text { Operations in Controlled Zones under conditions } 1 \text { to } 6 \mathrm{~km} \text { from the } \\
\text { airport boundary below } 30 \mathrm{~m} \text { (if UAV weighs } \leq 600 \mathrm{~g} \text { ) or more than } \\
6 \mathrm{~km} \text { from airport boundary above } 100 \mathrm{~m} \text { (if UAV weighs } \leq 25 \mathrm{~kg} \text { ) }\end{array}$ \\
\hline
\end{tabular}

The value of $r_{3}$ coefficient refers to the number of people over whom the flight is performed and is assigned according to the principle set out in table 4 .

Table 4

Indicators on populations density

\begin{tabular}{|c|c|}
\hline Populations density & The value of $\mathrm{r} 3$ \\
\hline 1 person $/ 1 \mathrm{~m}^{2}$ (e.g. stadium) & 10 \\
\hline 1 person $/ 10 \mathrm{~m}^{2}$ (e.g. busy street) & 8 \\
\hline 1 person $/ 100 \mathrm{~m}^{2}$ (e.g. park) & 5 \\
\hline 1 person $/ 1000 \mathrm{~m}^{2}$ (e.g. quiet street) & 1 \\
\hline 1 person $/ 10000 \mathrm{~m}^{2}$ (e.g. field) & 3 \\
\hline
\end{tabular}

The value of the $\mathrm{r}_{4}$ component is determined using a checklist consisting of 20 questions, a fragment of which is presented below (table 5). For each negative answer the operator gets 5 points, so that he/ she can get a minimum of 0 points (the best result) and a maximum of 100 (the worst result). If the answer given by the operator coincides with the blue field, the operator receives 0 points. If it coincides with the white field, 5 points are awarded for each answer. 


\section{Table 5}

\section{Preflight checklist}

\begin{tabular}{|c|c|c|c|}
\hline \multirow{2}{*}{ O.n. } & \multirow{2}{*}{ Questions } & \multicolumn{2}{|c|}{ Answer } \\
\hline & & YES & NO \\
\hline \multicolumn{4}{|c|}{ Group of questions - operator } \\
\hline 1 & $\begin{array}{l}\text { Do you have your qualification certificate, aeronautical examination, } \\
\text { insurance and ID card with you? }\end{array}$ & & \\
\hline 2 & $\begin{array}{l}\text { Have you consumed in the past } 24 \text { hours alcohol or drugs that effect } \\
\text { physical or mental coordination? }\end{array}$ & & \\
\hline & $\ldots$ & & \\
\hline \multicolumn{4}{|c|}{ Group of questions - technical condition of the UAV } \\
\hline 6 & $\begin{array}{l}\text { Are cracks, dirt or other defects that affect flight safety visible on the } \\
\text { UAV? }\end{array}$ & & \\
\hline 8 & $\begin{array}{l}\text { Does the Fail-Safe system work and is programmed according to the } \\
\text { current conditions? }\end{array}$ & & \\
\hline & $\ldots$ & & \\
\hline \multicolumn{4}{|c|}{ Group of questions - take off/landing place } \\
\hline 11 & $\begin{array}{l}\text { Have you checked the location (AIP) and the activity (AUP) of the air } \\
\text { zones and NOTAM? }\end{array}$ & & \\
\hline 13 & $\begin{array}{l}\text { Did you get acquainted with the topography of the area? Do you know } \\
\text { where the nearest hills, reservoirs, forests, etc. are? }\end{array}$ & & \\
\hline & $\ldots$ & & \\
\hline \multicolumn{4}{|c|}{ Group of questions - environmental conditions } \\
\hline 16 & Are there any precipitation or fog? & & \\
\hline 18 & Is the solar activity significant? & & \\
\hline
\end{tabular}

The method assumes that the operator of the unmanned aircraft has the required authorization to perform the commissioned operation, has a valid qualification certificate, the intention is not to break the law and wants to make the best flight and the operation is performed according to the VLOS principles.

An additional element affecting the risk value is the assessment performed by the organization as part of the internal audit or by the appropriate state body (e.g. CAA). Based on the assessment of company safety results based on the number of 
accidents and the experience of operators, one of three categories is awarded: A, B or $\mathrm{C}$ which affects the operator's final result (table 6).

Table 6

\section{Safety categories awarded to the organization}

\begin{tabular}{|c|c|}
\hline Category based on audit & Multiplier \\
\hline A & 1 \\
\hline B & 1,5 \\
\hline C & 2 \\
\hline
\end{tabular}

To give the enterprise a category, the $\alpha$ (average number of months of experience) is given on the basis of the average time of holding valid qualifications certificates of all operators in the organization. Assuming that the detailed rules for obtaining the described document are included in the Regulation of the Minister of Transport, Construction and Maritime Economy of 3 June 2013 on qualifications certificates (journal of Laws, item 664), the maximum "experience" is 5 years of holding a qualification certificate $(2013-2018)$. Therefore, 3 subcategories were distinguished: $\alpha \mathrm{A}, \alpha \mathrm{B}, \alpha \mathrm{C}$ (table 7).

Table 7

\section{Operators' experience subcategories}

\begin{tabular}{|c|c|}
\hline Subcategory & $\begin{array}{c}\text { Average number of months of } \\
\text { experience }(\alpha)\end{array}$ \\
\hline$\alpha \mathrm{A}$ & $37-60$ \\
\hline$\alpha \mathrm{B}$ & $13-36$ \\
\hline$\alpha \mathrm{C}$ & $0-12$ \\
\hline
\end{tabular}

Next, the accident rate $\omega$ is calculated from the formula:

$$
\omega=\frac{\text { accidents number }}{\text { number of UAV in use }}
$$

The numerator shows the number of accidents in the organization from the last 12 months, and the denominator - number of UAV in the company. The granting of one of the subcategories $(\omega \mathrm{A}, \omega \mathrm{B}, \omega \mathrm{C})$ is carried out according to the table 8 . 


\section{Table 8}

Subcategories applies to the accident rate

\begin{tabular}{|c|c|}
\hline Subcategory & Współczynnik wypadkowości $(\omega)$ \\
\hline$\omega \mathrm{A}$ & $\omega<1$ \\
\hline$\omega \mathrm{B}$ & $\omega=1$ \\
\hline$\omega \mathrm{C}$ & $\omega>1$ \\
\hline
\end{tabular}

On the basis of specific subcategories, the company is awarded one of three categories (A, B, C) according to the table 9:

Table 9

Assignment of categories based on a subcategory

\begin{tabular}{|c|c|c|c||}
\hline & $\omega \mathrm{A}$ & $\omega \mathrm{B}$ & $\omega \mathrm{C}$ \\
\hline$\alpha \mathrm{A}$ & $\mathrm{A}$ & $\mathrm{A}$ & $\mathrm{B}$ \\
\hline$\alpha \mathrm{B}$ & $\mathrm{A}$ & $\mathrm{B}$ & $\mathrm{C}$ \\
\hline$\alpha \mathrm{C}$ & $\mathrm{B}$ & $\mathrm{C}$ & $\mathrm{C}$ \\
\hline
\end{tabular}

After obtaining the result of a comprehensive risk assessment, the minimum value of which is 0 , and the maximum value is 6000 , the risk level is determined using the risk matrix (table 10). It takes into account the risk value obtained and the UAV weight class. The table has been marked according to the relationships: A - indicates acceptable level of risk (you can perform the operation and the risk should be monitored), $\mathrm{T}$ - means tolerable level of risk (you can do the operation but you must apply some risk mitigation measures), $\mathrm{N}$ - unacceptable level of risk (you cannot do operations without risk mitigation measures).

Table 10

Matrix of risk levels

\begin{tabular}{|l|c|c|c|c|c|}
\hline \multicolumn{1}{|c|}{$\begin{array}{l}\text { Risk } \\
\text { value }\end{array}$} & $\mathrm{C} 0$ & $\mathrm{C} 1$ & $\mathrm{C} 2$ & $\mathrm{C} 3$ & $\mathrm{C} 4$ \\
\hline $0-600$ & $\mathrm{~A}$ & $\mathrm{~A}$ & $\mathrm{~T}$ & $\mathrm{~T}$ & $\mathrm{~T}$ \\
\hline $601-2000$ & $\mathrm{~A}$ & $\mathrm{~T}$ & $\mathrm{~T}$ & $\mathrm{~T}$ & $\mathrm{~N}$ \\
\hline $2001-6000$ & $\mathrm{~T}$ & $\mathrm{~T}$ & $\mathrm{~T}$ & $\mathrm{~N}$ & $\mathrm{~N}$ \\
\hline
\end{tabular}


The risk classes are taken according to table 10 . The lower the risk value the operator gets, the heavier the UAV may operate with the acceptable or tolerable risk level. In addition, if the operator wants to operate a larger UAV and maintain the level of risk allowing the performance of operations, he must take care of the high safety culture in the organization. To facilitate the interpretation of the results, a three-color scale was used. In the scale green indicates the acceptable risk level, yellow means tolerable and red - unacceptable. In cases of tolerated risk, risk management should be applied. Examples of risk mitigation measures may include: annual firs aid course for operators, checking the technical condition of UAV before and after operation, navigation training and more.

\section{Summary}

The development of various fields of science (including optoelectronics and computer science) as well as the development of new structural solutions resulted in a drop in the production costs of UAV. The drop contributed to their entry into the commercial market. The rapid development of the sector poses high requirements connected with legal regulations concerning inter alia, protection of privacy and security. The share of unmanned aviation in all air operations carried out in Poland is constantly growing. Airspace is being used better and the coordination of UAV with General Aviation (GA) and Commercial Air Transport (CAT) is improving. Due to the continuous development of air traffic in uncontrolled areas (including urban spaces), it is necessary to undertake attempts to comprehensively manage risk in all types of aviation.

Therefore, it was decided to develop an affordable, user-friendly and easily implemented risk assessment method in the organization on unmanned aircraft operations. The analysis begins with describing the UAV use area, then selected methods of risk analysis were presented in order to show the appropriate path for creating an original method of risk assessment. The most important criteria influencing the safety of unmanned operations have been determined. It was found that with the assumptions made. The parameters on which the operator has the greatest impact is the preparation for flight in the aspects given in a checklist, the size of UAV and the safety category granted to the organization. The rest depends on the type of operation performed. 


\section{References}

1. Galant M. Ograniczenie ryzyka zagrożeń w lotnictwie ogólnym przez zastosowanie systemu monitorującego stan psychofizyczny pilota. Rozprawa doktorska. Politechnika Poznańska, Poznań 2017.

2. Heinrich O., Drone laws in Europe. dronerules.eu

3. http://ulc.gov.pl

4. International Civil Aviation Organization, Manual on Remotely Piloted Aircraft Systems (RPAS), Doc. 10019 ICAO, first edition 2016.

5. Klich E., Bezpieczeństwo lotów, Wydawnictwo Instytutu Technologii Eksploatacji, Radom 2011.

6. Rozporządzenie Ministra Infrastruktury i Rozwoju z dnia 5 sierpnia 2015 r. W sprawie szczegółowych wymagań w zakresie dokumentów oraz informacji, jakie jest obowiązany przedstawić przedsiębiorca ubiegający się o koncesję lub wykonujący działalność gospodarczą w zakresie przewozu lotniczego.

7. Rozporządzenie Ministra Transportu, Budownictwa i Gospodarki Morskiej z dnia 26 marca 2013 r. w sprawie wyłączenia zastosowania niektórych przepisów ustawy Prawo lotnicze do niektórych rodzajów statków powietrznych oraz określenia warunków i wymagań dotyczących używania tych statków 